\title{
Las cenizas de cáscaras de arroz utilizadas para reducir la temperatura del hormigón en masa, de alta resistencia
}

Dr. P. K. MEHTA y Prof. B. PIRT\%

A.C.I. Journal. Febrero 1978. Tituln N.4 75. 7

El Prof. P. K. Mehta ha puesto de manifiesto que las cenizas de las cáscaras del arroz tienen las propiedades de una sílice muy reactiva.

En unión con el Prof. Pirtz publica, en la revista y con el título mencionados, los resultados de un trabajo de investigación realizado con el objeto de conocer si se puede obtener un hormigón de alta resistencia, sin excesiva elevación de temperatura adiabática al reemplazar parcialmente el cemento portland por el material silícico, altamente reactivo, obtenido en la incineración de las cáscaras del arroz, según el procedimiento descrito por Mehta y N. Pitt en "Roesource Recovery and Conservation (Asterdam)" V. 2 n. ${ }^{\circ} 1,1976$, págs. 23-28.

Para esta investigación se utilizó un cemento portland tipo ASTM II. La sílice amorfa contenida en las cenizas se apreció por análisis químico y difractometría $\mathrm{X}$ obteniéndose valores superiores al $85 \%$ en peso.

La superficie específica de las cenizas, medida por adsorción de nitrógeno, fue de $55 \mathrm{~m}^{2} / \mathrm{g}$, alrededor de 150 veces mayor que la obtenida por el mismo método, con el portland. La densidad de las cenizas fue de $2,1 \mathrm{~g} / \mathrm{cm}^{3}$. Los áridos utilizados fueron: arena con módulo de finura 2,52. Gravas de $18 \mathrm{~mm}$ y de $37 \mathrm{~mm}$. Las dos gravas cumplían las especificaciones AISTM N. ${ }^{\circ} 67$ y 467.

\begin{tabular}{|c|c|c|}
\hline $\begin{array}{l}\text { Cemento } \\
\text { Cenizas } \\
\text { Agua } \\
\text { Arena } \\
\text { Grava } 18 \mathrm{~mm} \\
\text { Grava } 37 \mathrm{~mm}\end{array}$ & $\begin{array}{l}377 \\
-150 \\
676 \\
600 \\
606\end{array}$ & $\begin{array}{l}237 \\
102 \\
143 \\
717 \\
600 \\
606\end{array}$ \\
\hline Propiedades del hormigón & Portland & Portland con cenizas \\
\hline $\begin{array}{l}\text { Asentamiento } \mathrm{mm} \\
\text { Aire \% } \\
\text { Relación agua/cemento } \\
\text { Resistencia a compresión } 7 \text { días } \\
\text { Resistencia a compresión } 28 \text { días }\end{array}$ & $\begin{array}{l}95 \\
145 \\
0,40 \\
316 \mathrm{kp} / \mathrm{cm}^{2} \\
391 \mathrm{kp} / \mathrm{cm}^{2}\end{array}$ & $\begin{array}{l}13 \\
1,2 \\
0.42 \\
331 \mathrm{kp} / \mathrm{cm}^{2} \\
444 \mathrm{kp} / \mathrm{cm}^{2}\end{array}$ \\
\hline
\end{tabular}


Incremento adiabático de la temperatura, en grados centígrados

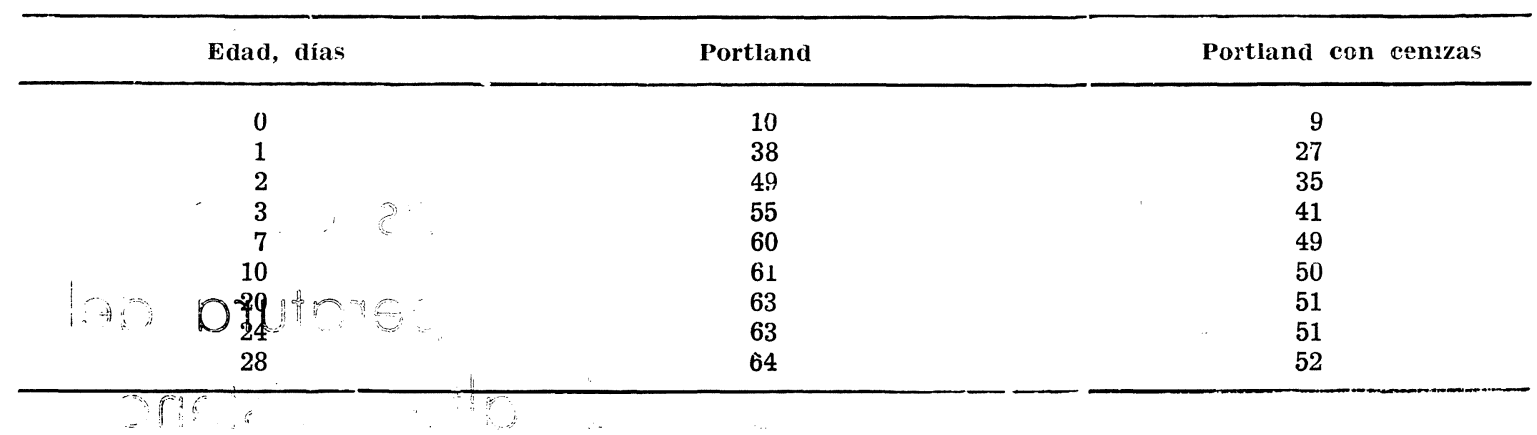

El hormigón que contiene cenizas de cáscaras de arroz alcanza unas resistencias a compresión mayores, en $5 \%$ a los 7 días y en $8 \%$ a los 28 días que el hormigón de sólo portland; éste es notable pues en el hormigón con cenizas hay un $10 \%$ menos de materiales cementicios.

Durante el tiempo del ensayo el hormigón da portland experimentó una elevación adiabática de temperatura de $35^{\circ} \mathrm{C}$, mientras en el hormigón con cenizas la elevación fue de $25^{\circ} \mathrm{C}$, a pesar da que el horm:gón de cenizas alcanzó mayor resistencia que el de sólo portland.

Debido a la excepcionalmente alta área superficial de las cenizas el hormigón que las contiene ofrece un asentamiento de sólo $13 \mathrm{~mm}$ comparado con los $95 \mathrm{~mm}$ del hormigón de portland. Durante la preparación se observó que el ensayo de asentamiento no refleja la docilidad del hormigón con cenizas, el cual, a pesar de tan bajo asentamiento, presentó mayor docilidad y, en el calorímetro adiabá ico, endureció una hora después de amasado.

P. G. de P. (IETCC) 